\title{
Neurohormonal control of intestinal transit
}

\author{
L Bueno, J Fioramonti
}

INRA, Department of Pharmacology, BP 3, 31931 Toulouse, France

\begin{abstract}
Summary - This review shows that numerous neuropeptides and hormones are involved in the regulation of intestinal transit. Many gastrointestinal hormones known to act on smooth muscle to influence muscle contractility also play a role in the genesis of abrupt changes associated with alimentary behaviour. In many monogastrics and ruminants, the cyclic occurrence of the migrating motor complex (MMC) is linked to peripheral hormonal factors only slightly influenced by the nature of food. Motilin is the major homone involved in triggering the gastric migrating motor complex while somatostatine and enkephalins are implicated in the propagation along the small intestine. Other hormones, like CCK8, insulin, gastrin, and neurotensin, trigger the development of an intestinal feed pattern but CCK released at the central nervous system ventromedial hypothalamus is involved in maintaining the postprandial type of activity. Gastrointestinal transit may be altered in physiopathological situations in which CRF, TRH and some cytokines (IL1 $\beta$, TNF $\alpha$ ) play an important role.
\end{abstract}

gastrointestinal tract / colon / motility / transit / hormone / neuropeptide / brain / motilin / CCK

Résumé - Contrôle neuro-hormonal du transit intestinal. De nombreux peptides et hormones digestives sont impliqués dans la régulation du transit intestinal. Is agissent soit directement sur la cellule musculaire lisse, soit possèdent des sites d'action relevant de l'innervation intrinsèque mais peuvent agir également au niveau supraspinal où ils sont responsables des adaptations motrices rapides en réponse à des stimuli externes tels que la prise alimentaire. Chez la plupart des monogastriques et chez les ruminants, l'apparition de cycles réguliers d'activité motrice que constituent les complexes moteurs migrants (CMM) est liée à des variations cycliques de la libération d'une hormone digestive : la motiline, indépendemment de facteurs alimentaires externes. La propagation de cette activité est sous le double contrôle de la somatostatine et des enképhalines. D'autres hormones telles que la CCK8, l'insuline, la gastrine et la neurotensine sont impliquées à plusieurs niveaux pour initier le profil d'activité postprandiale mais la CCK libérée au niveau de l'hypothalamus ventromédian intervient de façon privilégiée pour maintenir ce profil pendant toute la phase digestive. Enfin, récemment, il a été montré que les altérations motrices dans des situations physiopathologiques relèvent de l'intervention de peptides spécifiques (CRF, TRH) ou de certaines cytokines (IL1 $1, T N F \alpha)$ dont les mécanismes d'action ne sont pas totalement élucidés.

appareil digestif / côlon / motricité / transit / hormones / neuropeptides / fibres / motiline / cCK/aliments 


\section{INTRODUCTION}

The major function of the intestine is to digest food, assimilate nutrients and expel nondigestible residues. These functions are directly related to its motility which is responsible for the intestinal delivery and transport of digesta.

The fact that feeding affects gastrointestinal motility has been known since the last century when Beaumont (1833) described the changes in amplitude and frequency of gastric contractions associated with feeding. From 1940, improvements of our knowledge of mechanical events occurring in the digestive tract were associated with the development of manometric methods which permitted the recognition of the major patterns of gastrointestinal motility. However, a major step was linked to the use of electromyographic techniques, which have allowed a clear identification of the characteristics of the fasted pattern, ie the migrating motor (or myoelectric) complex (MMC) in dogs (Szurszewski, 1969) and in other animal species (Buéno et al, 1975; Ruckebusch and Fioramonti, 1975). Recently, it has been shown that the motor changes associated with feeding are related to the nature of food and caloric intake and that some peptides play a specific role in their genesis.

\section{PATTERNS OF MOTILITY AND DIGESTIVE STATUS}

\section{Stomach}

In many species, manometric recordings of antral motility during fasting or interdigestive periods exhibit a cyclic pattern of highamplitude contractions grouped in phases separated by periods of quiescence and appearing at 90-120 min intervals. The important property of the proximal stomach is receptive relaxation, mediated by inhibitory neurons in vagal nerves (Abrahamsson, 1973), which enables it to accomodate food delivery by the œsophagus. The contractions of the corpus and the antrum are coordinated and a slow contraction of the corpus lasting approximately $30 \mathrm{~s}$ is associated with 3-5 more rapid contractions of the antrum (Gill et al, 1985). After a meal, the digestive pattern is characterized by steady low-amplitude contractions (4-5 per $\mathrm{min}$ ) in the gastric antrum with no significant motor activity in the gastric body.

A cyclic pattern of gastric motility has been found in the dog (Itoh et al, 1977) and in man (Rees et al, 1982). In the rat (Bueno et al, 1982) and the rabbit (Deloof and Rousseau, 1985) there is no cyclic organization of the gastric motility, and feeding induces an increase of both the amplitude and frequency of the contractions.

\section{Small intestine}

The basic motor pattern of many animal species investigated consists of MMCs, first identified as "a caudad band of large-amplitude action potentials starting in the duodenum and traversing the small bowel" (Szurszewski, 1969). Each MMC corresponds to 3 consecutive phases: phase 1 has little or no contractile activity (quiescent phase), phase 2 has intermittent and irregular contractions, while the contractions of phase 3 occur at their maximal rate, which is determined by the frequency of the slow waves. The duration of phase 3 activity is relatively constant, but that of other phases varies from cycle to cycle, depending on the flow of digesta (Ruckebusch and Bueno, 1977). Depending on the animal species, the MMC cycle length varies between 60 and $120 \mathrm{~min}$ (Bueno and Ruckebusch, 1978) except in rats in which MMCs recur at 15-20 min intervals (Ruckebush and Fioramonti, 1975).

Feeding is accompanied by a disruption of the intestinal MMC to give a 'postprandial' 
pattern characterized by the irregular occurrence of contractions similar to those observed during phase 2 of the MMC (Bueno et al, 1975; Code and Marlett, 1975).

This disruption of the MMC pattern is related to the energy content of the meal, the nature of nutrients and the frequency of meals. However, non-nutrient factors are also involved in the postprandial disruption of the MMC pattern, since sham-feeding delays the next phase 3 in man (Defilippi and Valenzuela, 1981). On the other hand, meal frequency modulates the effects of feeding on small intestinal motility. For example, in pigs (Ruckebusch and Bueno, 1976) and in rats (Ruckebusch and Ferre, 1973) ingestion of a daily large meal disrupts the MMC for several hours, while under ad libitum feeding the MMC frequency is similar to that observed in the fasted state. However, in adult and neonatal pigs, feeding a standard meal only induces a 1-h delay in the onset of the next phase 3 (Burrows et al, 1986; Rayner and Wenham, 1986).

\section{Large intestine}

A common feature of the colon in all mammalian species investigated is a duality of the contractile activity: tonic contractions corresponding to myoelectrical events characterized by prolonged series of short spike bursts and phasic contractions corresponding to isolated and propagated long spike bursts. However, the spatial and temporal organization of these 2 kinds of contractions, which form the colonic motor pattern, is specific to each mammalian species so far investigated. This pattern is independent of colonic anatomy and of the traditional regimen of the animal species, but gross similarities exist within species producing moulded faeces such as the pig, dog or man, and within species that form faeces in pellets, such as the rabbit or the sheep (Fioramonti, 1981).

The typical characteristic of colonic motility in man, not seen in animals, consists of a very low activity during the night (Frexinos et al, 1985). After a $3000-4000 \mathrm{~kJ}$ meal the frequency of colonic contractions is increased for 2-3 $\mathrm{h}$. Such an increase in colonic motility after a meal seems to be a common feature.

\section{RELATIONSHIPS BETWEEN MOTILITY AND FLOW OF DIGESTA}

\section{Stomach}

In terms of transit of digesta, the 3 major functions of the stomach are the receipt of food, the storage of ingested food and the emptying of liquids and solids.

The entry of a large amount of food into the stomach leads to adaptive (or receptive) relaxation of the proximal part of the stomach acting as a reservoir (Jahnberg, 1977). The rhythmic contractions of the distal stomach are thought to control the trituration and emptying of solids, whereas the tonic contractions of the proximal stomach govern the rate of emptying of liquids. The pylorus prevents duodenogastric reflux, but is also a true sphincter which controls the empyting of food from the stomach.

\section{Small intestine}

The greatest flow of digesta occurs during the postprandial disruption of the MMC pattern, but the role of MMCs in the propulsion of digesta is not negligible since, at least in dogs, gastric emptying in not terminated when the MMCs reappear on the jejunum (Banta et al, 1979). However the propulsive role of each phase of the MMC still remains 
controversial depending on the experimental model: the maximal transit rate of a marker has been found associated with phase 3 using a jejunal isolated loop (Sarr et al, 1980) or with phase 2 when experiments were performed on an intact intestine in the same species.

Using an electromagnetic flowmeter to measure digesta flow continuously and electromyography to record intestinal motility, it has been observed in sheep that the majority of intestinal contents flowed intermittently for periods of 10-15 min at the same frequency as the MMC (fig 1). Two-thirds of this flow occurred in the 4-6 min immediately preceding the periods of phase 3 migration (Bueno et al, 1975).
Postprandial contractile patterns and transit and the distance over which the contractions are propagated vary according to the nature of the ingesta (fig 2) (Schemann and Hans-Jörg, 1986).

Eventhough there are clear relationships between motility patterns and chemical contents of the food, the physical nature of the digesta and particularly its viscosity plays an important role in the efficacy of propulsive waves. In dogs, it has been established that similar patterns of intestinal motility are induced by bran and cellulose but with very different rates of propulsion while bran and guar gum induce similar transit time (fig 3) but with different motor patterns (Bueno et al, 1981).
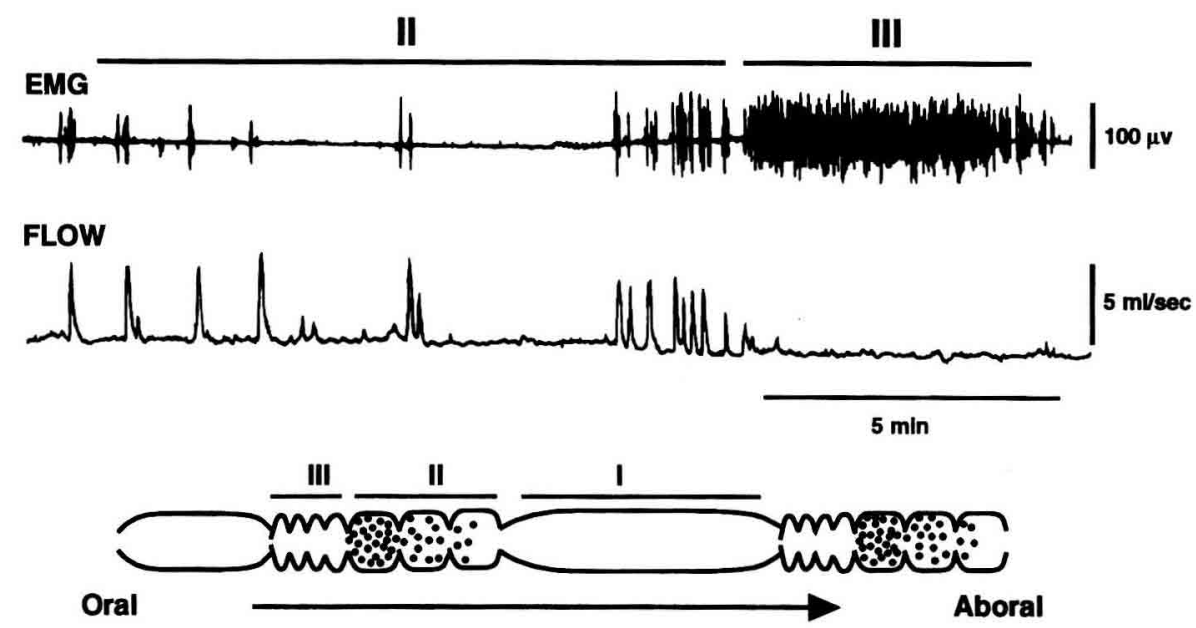

Fig 1. Stimultaneous recording of spiking myoelectrical activity and flow of digesta in the jejunum in sheep. The greatest flow occurs at the end of phase II. No flow was observed during phase III following phase II or during phase $\mathrm{I}$.

FIg 2. Motor patterns after different meals. Dashed lines indicate propagative contractions that led to contraction waves spreading over various distances; solid lines indicate simultaneously occurring contractions at adjacent recording sites ( $J$ to $\mathrm{J} 6$ : sites located at $10 \mathrm{~cm}$ intervals) that interrupt the propagation of contraction waves; triangles indicate stationary contractions occurring at one recording site only; the clusters of contractions are underlined. All nutrients decreased the number of contraction waves and increased the incidence of stationary contractions waves and increased the incidence of stationary contractions. Clusters of contractions were most obvious after the oleic acid meal. (Adapted from Schemann and Hans-Jörg, 1986.) 

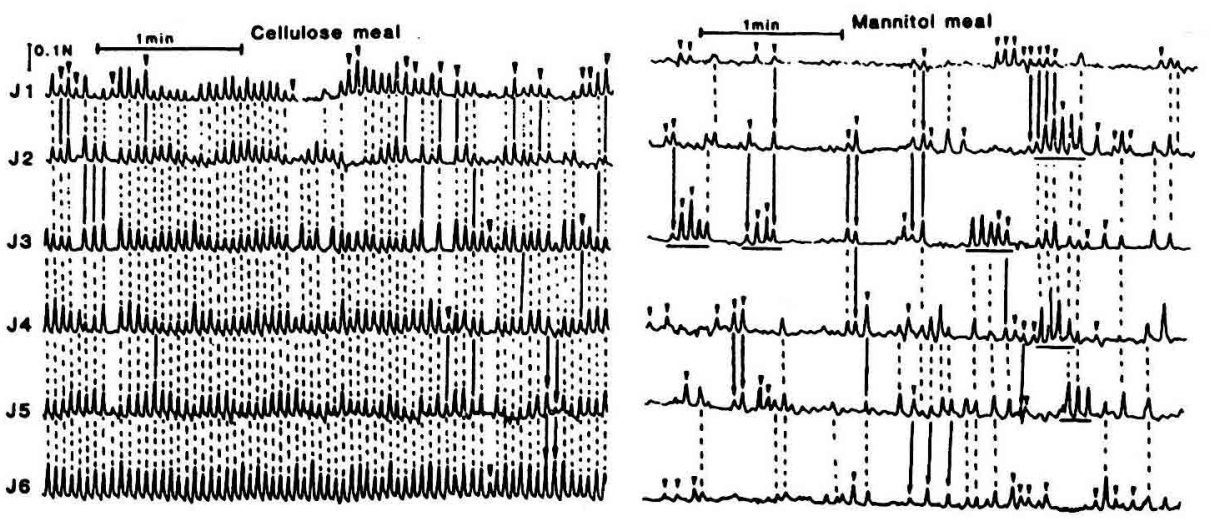

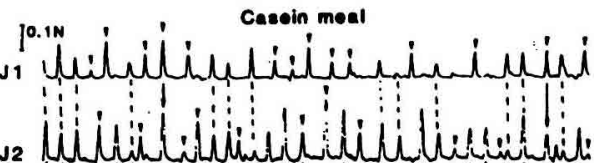

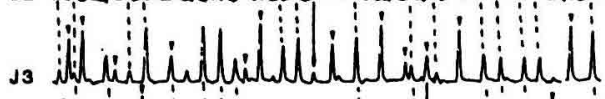

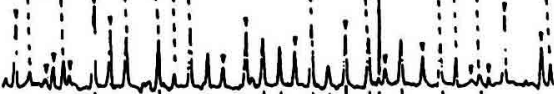

s.

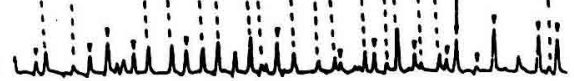
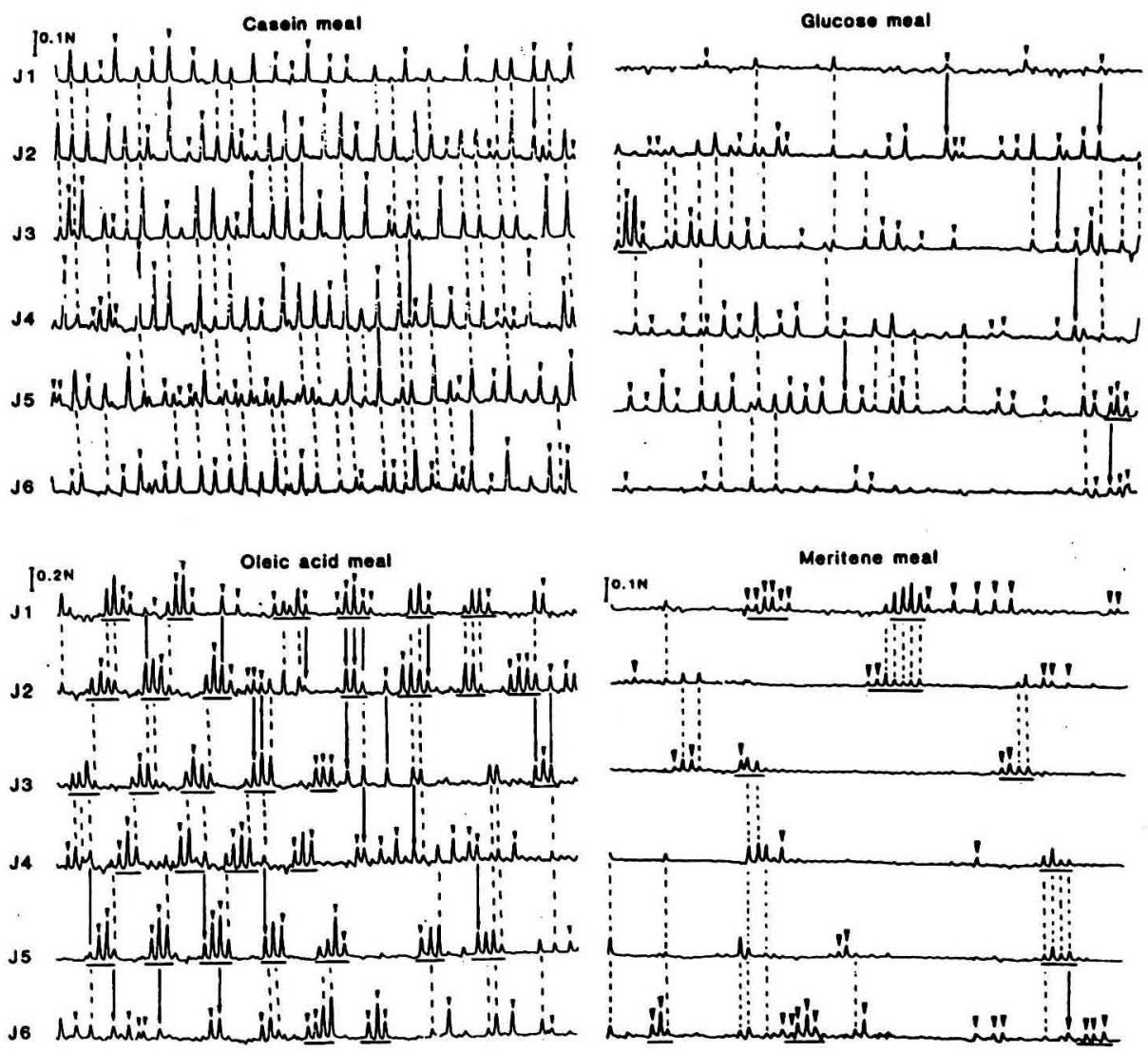


\section{LARGE INTESTINE}

The 2 kinds of colonic contractile activity have opposite effects on the propulsion of digesta. Phasic contractions ensure the mixing and the aboral progression of colonic contents while the tonic activity acts as a brake.
In dogs, the spontaneous fluctuations of the phasic activity are positively correlated with the spontaneous changes in the velocity of transit of a marker introduced in the proximal colon (Fioramonti et al, 1980). Similarly in pigs, a low-residue diet induces a 3 -fold increase in colonic mean retention
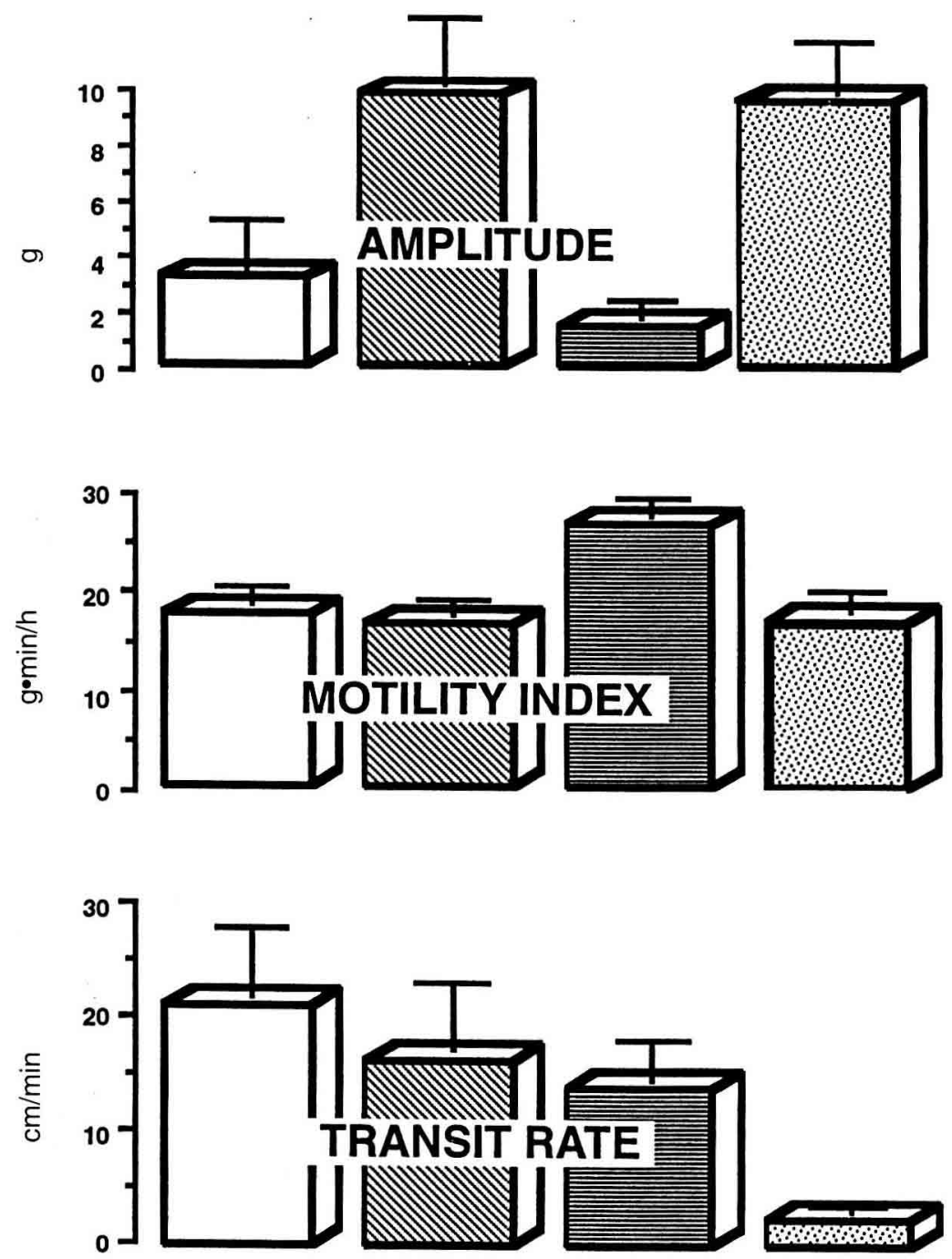

Fig 3. Relationships between the amplitude of contractions, corresponding motility index and rate of transit at jejunal level in relation with addition of similar amount $(30 \mathrm{~g})$ of fibers to the daily meal in dogs. (Adapted from Buéno et al, 1981.) $\square$ Standard meal; bran; gum; cellulose. 
time which was related to a decrease in phasic activity and an increase in tonic activity (Fioramonti and Bueno, 1980) (fig 4).

However, in humans, despite the many studies of colonic motility or colonic transit time, relations between muscle activities and digesta movement have not been fully elucidated.

\section{NEUROHORMONAL FACTORS}

\section{Hormones involved}

Among the hormones released during a meal, gastrin (Weisbrodt et al, 1974; Marik and Code, 1975; Wingate et al, 1978a),

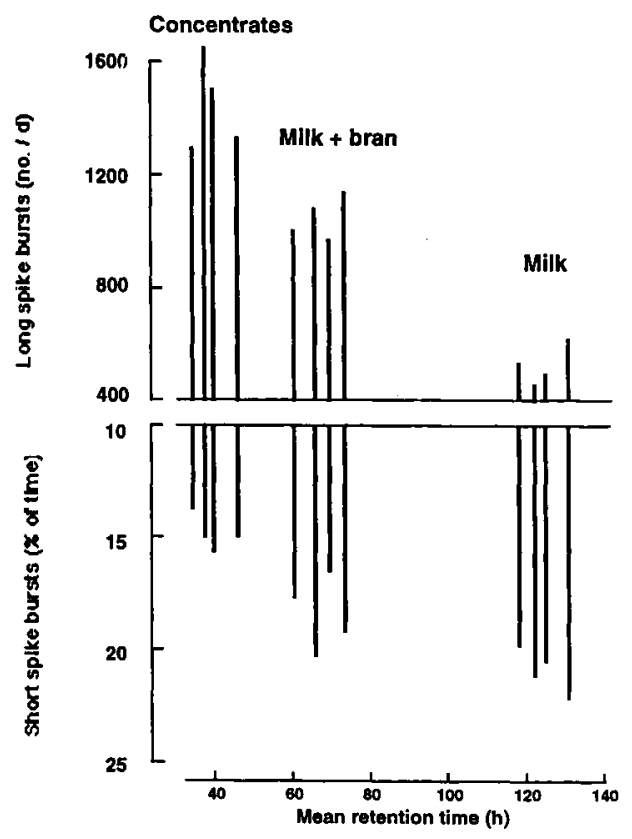

Fig 4. Relationship between colonic transit time and colonic spiking activity in 4 pigs on 3 different diets. The lowest long spike burst (LSB) activity and the highest short spike burst (SSB) activity are associated with a prolonged transit time on a fibre-free diet (milk). (Adapted from Fioramonti and Buéno, 1980.) insulin (Bueno and Ruckebusch, 1976), cholecystokinin (CCK) (Mukhopadhyay et al, 1977; Wingate et al, 1978a), secretin, glucagon (Wingate et al, 1978b), and neurotensin (Al Saffar and Rosell, 1981; Thor et al, 1982) alter the pattern of intestinal motility and/or transit when infused intravenously. However, it is unlikely that a single hormone is responsible for the postprandial change of the gastrointestinal motor pattern since for each hormone there are arguments against a physiological motor action. For example, a long-lasting disruption of the MMC occurs after fat ingestion in dogs, but with no significant increase in plasma gastrin and insulin (Eeckhout et al, 1978). Indeed significant increases in gastrin and insulin concentrations in blood induced by glucose ingestion or intravenous infusion are not associated with a disruption of the MMC pattern (Eeckhout et al, 1978). Similarly the disruptive effect of insulin infusion on MMCs is abolished in pigs when a normal blood glucose level is maintained by a concomitant glucose infusion (Rayner et al, 1981). On the other hand, infusions of CCK or gastrin, or both, disrupt the duodenal MMC in dogs, but the cyclic peaks of motilin concentrations in blood persist, while in the same animals plasma motilin is reduced after a meal (Lee et al, 1980).

In both rats and humans, neurotensin infusion induces a pattern of intestinal contractions very similar to that observed after feeding and accelerates intestinal transit (AI Saffar and Rosell, 1981; Thor et al, 1982; Shaw and Buchanan, 1983). In rats intestinal neurotensin exhibits circadian variations, with a maximum during the night which corresponds to a period of intense ingestive behaviour associated with the disruption of MMCs (Ferris et al, 1986).

Regulation of the postprandial motility and transit by hormones is a very attractive hypothesis and hormones are undoubtedly involved in the disruption of the MMC, at least in the stomach, since feeding abolishes 
the MMC in an autotransplanted denervated fundic pouch (Thomas and Kelly, 1979). However, nervous factors are also of importance since vagotomy delays the onset of the fed pattern (Ruckebusch and Bueno, 1977) and reduces the intestinal transit. Furthermore, an experimentally induced increase in digesta flow lengthens the duration of phase 2 (Bueno and Fioramonti, 1980).

The motility of the colon is stimulated after feeding and intravenous infusion of postprandially released hormones, such as gastrin (Snape et al, 1978), CCK (Renny et al, 1983) or neurotensin (Thor and Rosell, 1986), stimulates colonic motility. However, no information is available to confirm a phys- iological role for these hormones in the control of the colonic motor response to eating for which a neural mechanism seems probable (Snape et al, 1979), associated with the entry of digesta into the colon in dogs (Fioramonti and Bueno, 1983).

Numerous findings indicate a link between the brain and the digestive tract in both physiological and pathological states. Table I summarizes most of the studies evidencing an effect of centrally administered peptides on gastrointestinal and colonic transit.

These peptides may be divided into 2 groups according to the digestive state and the corresponding effects on intestinal transit.

Table I. Comparative CNS influence of several peptides on gastrointestinal and colonic transit.

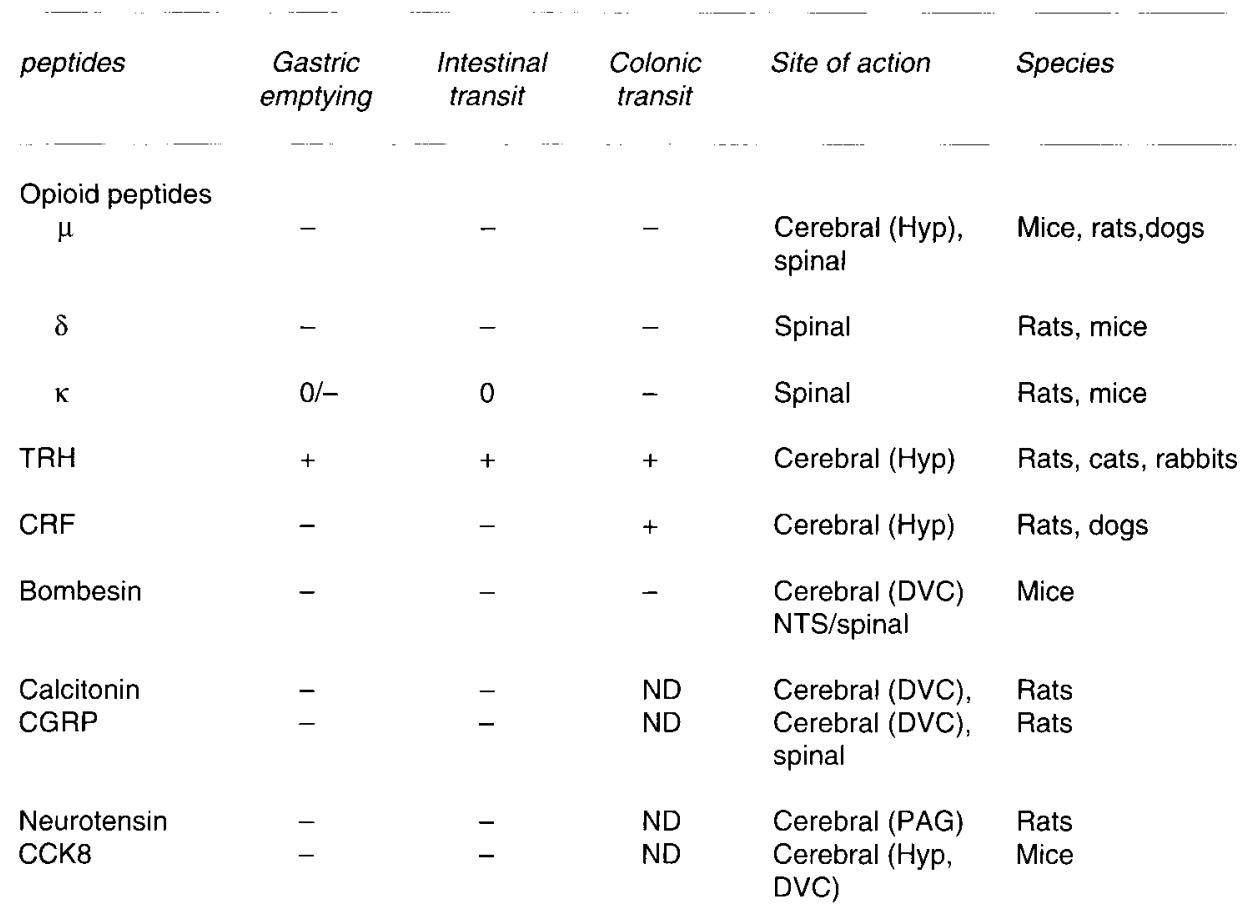

ND: not determined; Hyp: hypothalamic nucleus; DVC: dorsal vagal complex; PGM, periaqueductal grey matter + increase; - : decrease 
The first group includes peptides, like CCK, which disrupt the MMC pattern after central administration. After feeding, CCKlike immunoreactivity increases in the hypothalamus (Schick et al, 1987) and central administration of CCK induces a fed pattern in both rats (Bueno and Ferre, 1982) and dogs (Karmeli et al, 1987). More recently, it was shown in rats that the CCKA receptor antagonist devazepide injected bilaterally into the ventromedial nucleus of the hypothalamus (VMH) greatly reduces the duration of the postprandial pattern after a given meal, an effect not reproduced by similar administration into the lateral hypothalamus (Liberge et al, 1990). In addition while CCK microinjected into the VMH mimics the increase in colonic motility observed after a meal, devazepide injected in the same brain nucleus just prior to feeding abolishes the colonic response to the meal in rats. This result supports the hypothesis that CCK released in the central nervous system (CNS) of rats mediates the motor adaptation of the small intestine and the proximal colon to the postprandial state (Liberge et al, 1991).

At a peripheral level, the postprandial role of CCK in the control of the gastrointestinal motor pattern and intestinal transit may also be neuronal since CCK immunoreactivity has been demonstrated in axons and nerve cell bodies of the enteric nervous system (Larsson and Rehfeld, 1979). Circulating CCK may alter the motor activity directly by binding to specific receptors located on the smooth-muscle cell membrane (Morgan et al, 1978).

The second group of peptides with a central site of action on intestinal transit are those that restore a MMC pattern in the jejumum when given intracerebro-ventricularly after a meal. Such an effect is insufficient to prove a central physiological action, but it suggests that the CNS is involved in the normal postprandial disruption of the intestinal MMC pattern. For example, MMC dis- ruption can be blocked by icv administration of calcitonin, neurotensin or growth-hormone-releasing factor (Bueno et al, 1985) as well as interleukin (IL) $\beta$ at doses that are ineffective by systemic route.

\section{NUTRITIONAL IMPLICATIONS}

Intestinal transit, digestive secretions and intestinal absorption are closely related processes that control nutrient absorption and the digestion of food. Thus, the influence of food components on the release of gastrointestinal hormones may be considered as a link between nutrition, digestive motility and intestinal transit.

\section{Digestive secretions}

Exocrine secretion and mucosal absorption vary synchronously with patterns of motor activity and may also be affected by peptides that alter motility.

Pancreatic and biliary flow are associated with duodenal MMC. In dogs, maximal outputs of lipase (EC 3113) and bilirubin appear during the duodenal propagation of phase 3 activity (Dimagno et al, 1979). Similarly bile acids, trypsin and bicarbonate outputs are maximal during phase 3 activity (Keane et al, 1980) (fig 5). However, the amount of pancreatic enzymes secreted during phase 3 activity was found to be $50 \%$ of that secreted during a similar time following ingestion of meal.

\section{Intestinal absorption}

Studies of absorption in animals prepared with isolated intestinal loops indicate that the rate of digesta passage affects the uptake of nutrients (Sarr et al, 1980). In experiments with intact animals the maxi- 


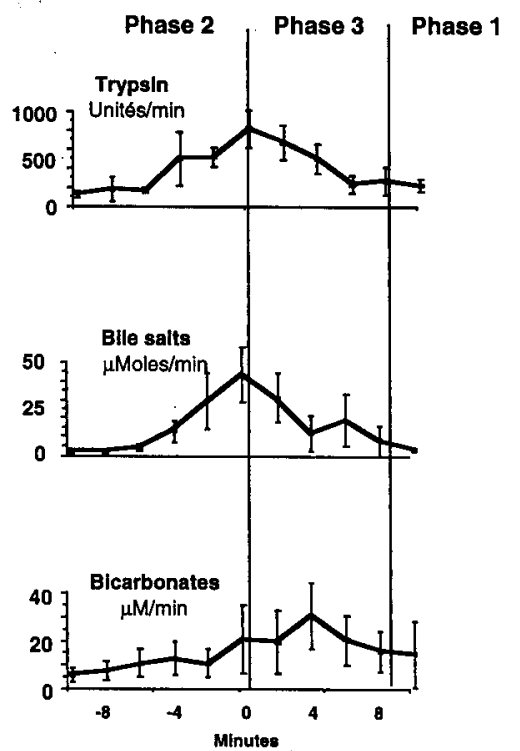

Fig 5. Relationships among duodenal MMC and pancreatic and biliary flow in dogs. The maximal output of trypsin, bile acids and bicarbonates appears at the onset of phase III. (Adapted from Keane et al, 1980.) mal absorption of glucose occurs during the later stages of phase 2 activity of the MMC (fig 6), when the rate of transit was fastest compared with other phases of the intestinal motor complex (Fioramonti and Bueno, 1983). These relationships between intestinal motility and absorption have been indirectly confirmed by the presence of the highest values of potential difference across the mucosa during phase 3 activity in dogs as well as in humans (Read, 1980). Moreover, mesenteric arterial blood flow, which controls passive paracellular absorption but also active transcellular transport through the oxygen supply, exhibits cyclic variations at the same frequency as recurrent MMC. Minimal blood flow occurs during the periods of intestinal motor quiescence (Fioramonti and Bueno, 1983) and maximal mesenteric blood flow is observed after a meal (Vatner et al, 1970). Digestive hormones act on smooth muscles of both the arteries and the small intestine, but their effects can be similar or opposite. For example, gastrin and CCK increase and somatostatin decreases

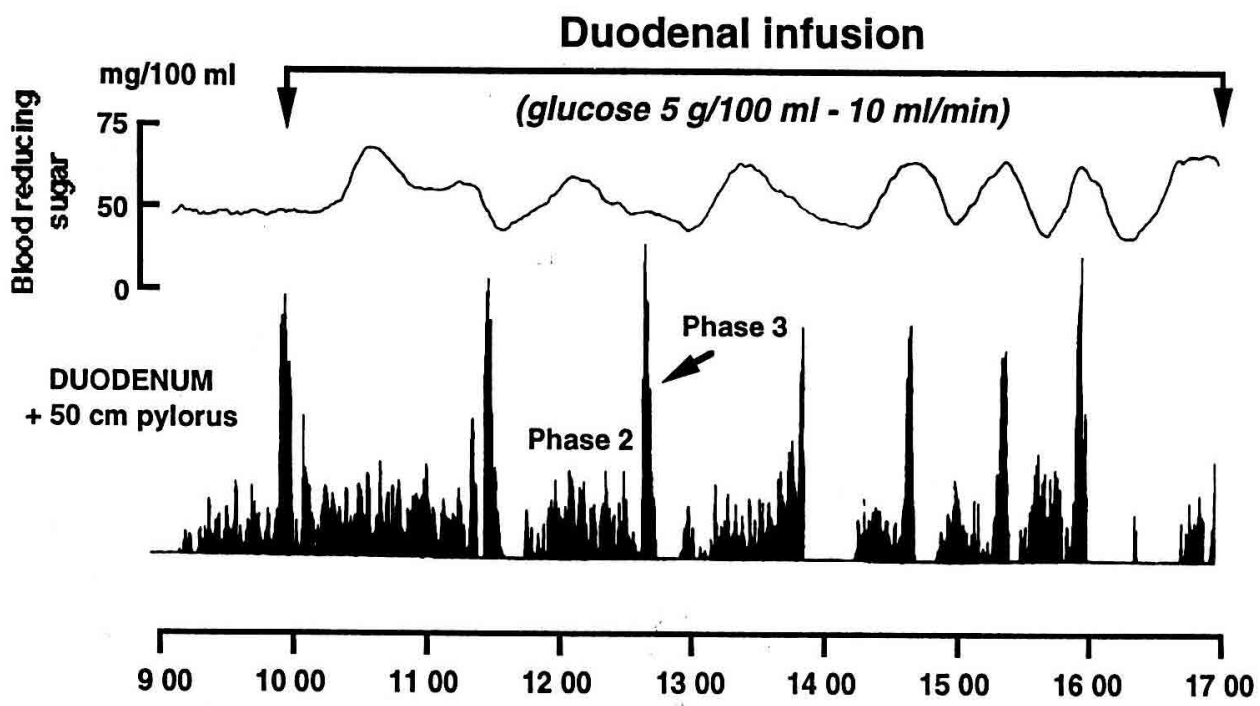

Fig 6. Relationships between glucose absorption and duodenal motility in the pig. Oscillations of glycaemia are the same frequency as duodenal MMC during continuous infusion of glucose into the duodenum. (Adapted from Fioramonti et al, 1980.) 
both blood flow and intestinal motility, while glucagon inhibits motility and increases blood flow (Fondacaro, 1984).

\section{CONCLUSIONS}

This review evidences that the regulation of gastrointestinal and colonic transit depends upon motility patterns, which are under the control of both peripheral and central neurohormonal factors. These factors are released in relation to the nature of nutrients to adapt the gut to the digestive status. However, the transit of digesta is also governed by the physical nature of the contents and a close reciprocal influence exists between absorptive and propulsive process.

\section{REFERENCES}

Abrahamsson $H$ (1973) Studies on the inhibitory nervous control of gastric motility. Acta Physiol Scand 390 Suppl 1-38

Al Saffar A, Rosell S (1981) Effects on neurotensin and neurotensin analogues on the migrating myoelectrical complexes in the small intestine of rats. Acta Physiol Scand 112, 203-208

Banta CA, Clemens ET, Krinsky MM et al (1979) Sites of organic acid production and patterns of digesta movements in the gastrointestinal tract of dogs. J Nutr 109, 1592-1600

Beaumont W (1833) Experiments and Observations on the Gastric Juice and the Physiology of the Digestion. FP Allen, Plattsburgh, NY, USA

Bueno L, Ruckebusch M (1976) Insulin release and jejunal electrical activity in dogs and sheep. Am J Physiol 230, 1538-1544

Bueno L, Ruckebusch Y (1978) Migrating myoelectrical complexes. Disruption, enhancement and disorganisation. Proc 6th int Symp Gastrointestinal Motiity (HL Duthie, ed), Edingburgh, 1977, MTP Press Ltd, Lancaster, UK, pp 83-90

Bueno L, Fioramonti J (1980) Rhythms of abomasointestinal motility In: Digestive Physiology and Metabolism in Ruminants ( $Y$ Ruckebusch, $P$ Thivend, eds). MTP Press Ltd, Lancaster, UK, pp 53-80

Bueno L, Ferre JP (1982) Central regulation of intestinal motility by somatostatin and cholecystokinin octapeptide. Science 216, 1427-1429
Bueno L, Fioramonti J, Ruckebusch Y (1975) Rate of flow of digesta and electrical activity of the small intestine in dogs and sheep. J Physio/ 249,69-85

Bueno L, Praddaude F, Fioramonti J, Ruckebush Y (1981) Effect of dietary fiber on gastrointestinal motility and jejunal transit in dog. Gastroenterology 80 , 701-707

Bueno L, Ferre JP, Fioramonti J et al (1982) Control of the antral motor response to feeding by gastric acid secretion in rats. J Physio/ 325, 43-50

Bueno L, Fargeas MJ, Fioramonti J et al (1985) Central control of intestinal motility by prostaglandins: a mediator of the action of several peptides in rats and dogs. Gastronterology 88, 1888-1894

Burrows CF, Meritt AM, Tash J (1986) Jejunal myoelectrical activity in the conscious neonatal pig, $J$ Physiol 374, 349-357

Code CF, Marlett JA (1975) The interdigestive myoelectric complex of the stomach and the small bowel of dogs. J Physiol 246, 298-309

Defilippi C, Valenzuela JE (1981) Sham feeding disrupts the interdigestive motility complex in man. Scand J Gastroenterol 16, 977-979

Deloof S, Rousseau JP (1985) Specific effects of thoracic vagotomy on the electrical activity of the gastric antrum and pylorus in rabbits. $Q J$ Exp Physio/ 70 , 491-501

Dimagno EP, Hendricks JC, Go VLW et al (1979) Relationships among canine fasting pancreatic and biliary secretions, pancreatic duct pressure, and duodenan phase III motor activity. Boldyreff revisited. Dig Dis Sci 24, 689-693

Eeckhout C, De Wever I, Peeters I et al (1978) Role of gastrin and insulin in postprandial disruption of migratin complex in dog. Am J Physiol 235, E666E669

Ferris CF, George JK, Albers HE (1986) Circadian rhythm of neurotensin levels in rat small intestine. Reg Pept 15, 285-292

Fioramonti J (1981) Etude comparée des fonctions motrices du gros intestin (a comparative study of large intestine motor functions). Doctoral Thesis, University of Toulouse, France

Fioramonti J, Bueno L (1980) Motor activity in the large intestine of the pig related to dietary fibre and retention time. Br J Nutr 43, 155-162

Fioramonti J, Bueno L (1983) Diurnal changes in colonic motor profile in conscious dogs. Dig Dis Sci $28,257-$ 264

Fioramonti J, Garcia-Villar R, Bueno L et al (1980) Colonic myoelectrical activity and propulsion in the dog. Dig Dis Sci 25, 641-646

Fondacaro JD (1984) Intestinal blood flow and motility. In: Physiology of the Intestinal Circulation (AP Sherpherd, DN Granger, editors). Raven Press, New York, NY, USA, 170-120 
Frexinos J, Bueno L, Fioramonti J (1985) Diurnal changes in myoelectric spiking activity of the human colon. Gastroenterology 88, 1104-1110

Gill RC, Pilot MA, Thomas PA et al (1985) Organization of fasting and postprandial myoelectric activity in stomach and duodenum of conscious dogs. Am J Physiol 249, G655-G661

Itoh Z, Aizawa I, Takeuchi S et al (1977) Diurnal changes in gastric motor activity in conscious dogs. Dig Dis $\mathrm{SCl}$ $22,929-935$

Jahnberg T (1977) Gastric adaptative relaxation. Scand $J$ Gastroenterol 12, Suppl, 1-32

Karmeli R, Kamei C, Schamlz P et al (1987) The effect of intracerebroventricular perfusion with CCK-OP on gastrointestinal myoelectric activity in the dog. Dig Dis Sci 32, 916

Keane FB, DiMagno EP, Dozois RR et al (1980) Relationships among canine interdigestive exocrine pancreatic and biliary flow, duodenal motor activity, plasma pancreatic polypeptide and motilin. Gastroenterology $78,310-316$

Larsson LI, Rehfeld UR (1979) Localization and molecular heterogeneity of cholecystokinin in the central and peripheral nervous system. Brain Res 165, 201218

Lee KY, Kim PS, Chey WY (1980) Effects of a meal and gut hormones on plasma motility and duodenal motility in dog. Am J Physiol 238, G280-G283

Liberge M, Arruebo P, Bueno L (1990) CCK8 neurons of the ventromedial (VMH) hypothalamus mediate the upper gut motor changes associated with feeding in rats. Brain Res 508, 118-123

Liberge M, Arruebo P, Bueno L (1991) Role of hypothalamic cholectstokinin octapeptide in the colonic motor response to a meal in rats. Gastroenterology 100 . $441-449$

Marik F, Code CF (1975) Control of the interdigestive myoelectric activity in dogs by the vagus nerves and pentagastrin. Gastroenterology 69, 387-395

Morgan KG, Schmalz PF, Go VLW et al (1978) Electrical and mechanical effects of molecular variants of CCK on antral smooth muscle. Am J Physiol 235 , E324-E239

Mukhopadhyay AK, Thor PJ, Copeland EM et al (1977) Effect of cholecystokinin on myoelectric activity of small bowel of the dog. Am J Physiol 232, E44-E47

Rayner V, Wenham G (1986) Small intestinal motility and transit by electromyography and radiology in the fasted and ted pig. J Physiol 379, 245-256

Rayner V, Weekes TEC, Bruce JB (1981) Insulin and myoelectric activity of the small intestine of the pig. Dig Dis Sci 26, 33-41

Read NW (1980) The migrating motor complex and spontaneous fluctuations of transmural potential difference in the human small intestine. In: Gastroin- testinal Motility (J Christensen, ed). Raven Press, New York, NY, USA, 299-306

Rees WCW, Malagelada JR, Miller LJ et al (1982) Human interdigestive and postprandial gastrointestinal motor and gastrointestinal hormone patterns. Dig Dis Sci 527, 321-329

Renny A, Snape WJ, Sun EA et al (1983) Role of cholecystokinin in the gastrocolonic response to a fat meal. Gastroenterology 85, 17-21

Ruckebusch M, Ferre JP (1973) Origine alimentaire des variations nycthémérales de l'activité électrique de l'intestin grêle chez le rat (alimentary origin of the nycthemeral variatons of intestinal activity in the rat). C R Soc Biol 167, 2005-2009

Ruckebusch M, Fioramonti J (1975) Electrical spiking activity and propulsion in small intestine in fed and fasted rats. Gastroenterology 68, 1500-1508

Ruckebusch Y, Bueno L (1976) The effect of feeding on the motility of the stomach and small intestine in the pig. Br J Nutr 35, 397-405

Ruckebusch Y, Bueno L (1977) Migrating myoelectrical complex of the small intestine. An intrinsic activity mediated by the vagus. Gastroenterology 73, 13091314

Sarr MG, Kelly KA, Phillips SF (1980) Canine jejunal absorption and transit during interdigestive and digestive motor states. Am J Physiol 239, G167-G172

Schemann M, Hans-Jörg E (1986) Postprandial patterns of canine jejunal motility and transit of luminal content. Gastroenterology 90, 991-1000

Schick RF, Reilly WM, Roddy DR et al (1987) Neuronal cholecystokinin-like immunoreactivity is postprandially released from primate hypothalamus. Brain Res $418,20-26$

Shaw C, Buchanan KD (1983) Intact neurotensin (NT) in human plasma: response to oral feeding. Regul Pept $7,145-153$

Snape WJ, Matarazzo A, Cohen S (1978) Effect of eating and gastrointestinal hormones on human colonic myolectrical and motor activity. Gastroenterology $75,373-378$

Snape WJ, Wright SH, Battle WM et al (1979) The gastrocolic response: evidence for a neural mechanism. Gastroenterology 77, 1235-1340

Szurszewski JH (1969) A migrating electric complex of the canine small intestine. Am J Physiol 217, 1757-1763

Thomas PA, Kelly KA (1979) Hormonal control of interdigestive motor cycles of canine proximal stomach. Am J Physiol 237, E192-E197

Thomas PA, Kelly KA, Go VLW (1979) Does motilin regulate canine interdigestive gastric motility? Dig Dis Sci 24, 577-582

Thor K, Rosell S (1986) Neurotensin increases colonic motility. Gastroenterology 90, 27-31

Thor K, Rosell S, Rokaeus A et al (1982) (GIn 4 )- neurotensin changes the motility pattern of the duode- 
num and proximal jejunum from a fasting-type to fed-type. Gastroenterology 83, 569-574

Vatner SF, Franklin D, Van Citters RL (1970) Mesentric vasoactivity associated with eating and digestion in the conscious dog. Am J physiol 219, 170-174

Weisbrodt NW, Copeland EM, Kearley RW et al (1974) Effects of pentagastrin on electrical activity of small intestine of the dog. Am J Physiol 277, 425-429
Wingate DL, Pearce EA, Hutton M et al (1978a) Quantitative comparison of the effects of cholecystokinin, secretin and pentagastrin on gastrointestinal myoelectric activity in the conscious fasted dog. Gut 19, 593-601

Wingate DL, Pearce EA, Thomas PA et al (1978b) Glucagon stimulates intestinal myoelectric activity. Gastroenterology 74, 1152 